\title{
Evaluation on the Hydrologic Effects after Applying an Infiltration Trench and a Tree Box Filter as Low Impact Development (LID) Techniques
}

\author{
Precious Eureka D. Flores • Marla C. Maniquiz-Redillas • Jevelyn Ann S. Tobio - Lee-Hyung Kim ${ }^{\dagger}$ \\ Department of Civil and Environmental Engineering, Kongju National University Cheonan City, Korea \\ 저영향 개발기법의 침투도랑과 나무여과상자 적용 후 수문학적 효과 평가 \\ Precious Eureka D. Flores · Marla C. Maniquiz-Redillas • Jevelyn Ann S. Tobio · 김이형 ${ }^{\dagger}$ \\ 공주대학교 건설환경공학부 \\ (Received 24 October 2014, Revised 16 December 2014, Accepted 17 December 2014)
}

\begin{abstract}
In this research, the hydrologic effects between a pre-existing urban landuse and low impact development (LID) applied conditions were compared and evaluated. The infiltration trench and tree box filter that were utilized in LID represent only $1 \%$ of the catchment area that they drain. Storm event monitoring were conducted from July 2010 to July 2014 on a total of 22 storm events in both LID sites. After LID, hydrological improvement was observed as the sites exhibited a delay (lag time) or reduction in the magnitude, frequency and duration of runoff and flow peaks as the rainfall progress. In addition, the maximum irreducible peak flow reduction for infiltration trench was found to be $61 \%$ and $33 \%$ for the tree box filter when rainfall was 40 $\mathrm{mm}$ and $30 \mathrm{~mm}$, respectively. In designing LID, it is recommended to consider the storage capacity and catchment area, as well as the amount of rainfall and runoff on the site.
\end{abstract}

Key words : Hydrologic effect, Low impact development, Peak flow, Rainfall, Runoff

\section{Introduction}

Urbanization is the continuous development of urban areas that has long been perceived as one of the adverse force affecting natural hydrologic cycle and stream ecosystem (McCuen, 1998). The major hydrologic effects of urbanization include the high fraction of precipitation converted to surface runoff, decreased in the lag time between rainfall and runoff, increase in peak flow magnitudes and reduced groundwater recharge capabilities (Hsu et al., 2000; Jacobson, 2011; Shaw, 1994; Shuster et al., 2005). Several studies indicated and examined the specific hydrologic effects of an urbanized area. According to Rose and Peters (2001), the peak flows in an urbanized area were most likely $30 \%$ to more than $100 \%$ greater than the non-urbanized land use. In addition, Cook and Dickinson (1985) has examined the hydrologic response of urbanization and found out that regardless of rainfall intensity or duration, the runoff coefficient increased by at least $50 \%$, and the lag time of concentration and peak flow was decreased by three-fold. Likewise, urban development contributes substantial amount of washed-

\footnotetext{
${ }^{\dagger}$ To whom correspondence should be addressed. leehyung@kongju.ac.kr
}

This is an Open-Access article distributed under the terms of the Creative Commons Attribution Non-Commercial License (http://creativecommons.org/ licenses/by-nc/3.0) which permits unrestricted non-commercial use, distribution, and reproduction in any medium, provided the original work is properly cited. off pollutants into the receiving waters which cause water quality degradation (Kim and Lee, 2005; Lee et al., 2007; Lee et al., 2008; Maniquiz et al., 2012).

Currently, the integration and linking of both the ecosystem and landscape planning is being considered to address the growing concern in water quantity and quality management (Hatt et al., 2007). In Korea, the Ministry of Environment has funded several projects related to the management of stormwater runoff and one of these is the application of low impact development (LID) technologies in the urban landuses. LID is an approach that manages stormwater by promoting the natural movement of water within the watershed, thus maintaining or restoring the watershed's hydrologic and ecological functions (Coffman, 2000; Davis, 2008). There are many practices that have been used in LID such as bioretention facilities, rain gardens, vegetated rooftops, rain barrels, permeable pavements, etc. Two of the most common LIDs implemented in urban landuses in Korea were infiltration trench and bioretention. The infiltration trench mainly captures and temporarily holds stormwater runoff prior to groundwater recharge (U.S. EPA, 1999). On the other hand, bioretention incorporate trees and other gardening plants to regulate and treat runoff from an impervious surface (Davis et al., 2009). Hood et al. (2007) reported that after the app- 
lication of common LID technologies on a residential area, the start of runoff-to-peak flow time was increased by almost $30 \%$ and peak flow was reduced for an estimate of $80 \%$. This research was conducted to evaluate the hydrologic effects of the infiltration trench (IT) and tree box filter (TBF) employed in LID for the management of stormwater runoff in a road and parking lot landuse inside a university campus.

\section{Materials and Method}

\subsection{Description of the LID Sites}

The two LID sites were located inside the Kongju National University campus grounds in Cheonan City, South Korea $\left(36^{\circ} 51^{\prime} 1.11^{\prime \prime N}, 127^{\circ} 9^{\prime} 0.23^{\prime \prime E}\right)$. Fig. 1 shows the hydrologic conditions before and after the application of LID, and the schematic diagrams of the two technologies employed in LID. In the pre-existing condition the stormwater runoff flows to the paved road and impervious parking lot which is directly discharged to the drainage system increasing the amount of runoff volume and flow peaks during storm events. The two technologies namely the infiltration trench and tree box filter employed in LID were constructed to provide hydrologic benefits such as runoff volume and peak flow reduction; and help restore the natural circulation system lost due to the impervious surfaces. The infiltration trench, with a surface area and storage volume of $5.0 \mathrm{~m}^{2}$ and $3.85 \mathrm{~m}^{3}$, respectively was constructed to manage stormwater runoff from a $520 \mathrm{~m}^{2}$ paved road with a $2.5 \%$ slope. The tree box filter, about half the size of the infiltration trench has a surface area of $1.5 \mathrm{~m}^{2}$ and storage volume of $0.56 \mathrm{~m}^{3}$ drains the runoff from a $450 \mathrm{~m}^{2}$ parking lot with a $0.33 \%$ slope. The surface area of the infiltration trench and tree box filter were only less than $1 \%$ of the total catchment area, and the storage volume was approximately $60 \%$ of the total volume.

The infiltration trench and tree box filter have pre-treatment component that captures and temporarily holds stormwater runoff, infiltration capability for ground water recharge and utilized filter media that aid in the filtration and storage of stormwater runoff. Although smaller than the infiltration trench, the tree box filter can perform additional hydrologic benefit such as evapotranspiration and plant uptake to regulate runoff from an impervious area.

\subsection{Storm Event Monitoring}

A total of 13 storm events were monitored in the infiltration trench from July 2010 to April 2014 and nine storm events in the tree box filter from July 2010 to July 2014. The rainfall data for all the storm events were obtained from the Korean Meteorological Association (KMA). Flow measurements were manually conducted at the inflow and outflow units of the infiltration trench and tree box filter in five minute interval from the start until the end of runoff/ outflow. The flow rates were calculated as the volume of runoff collected in a graduated container or volumetric flask per unit time.

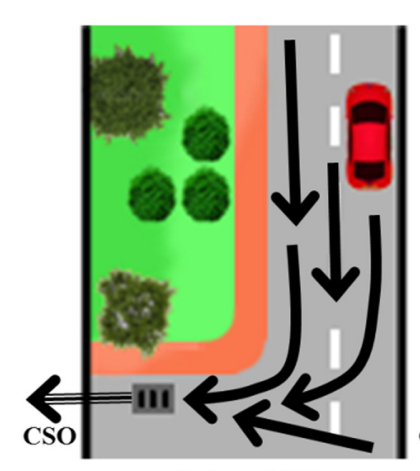

Before LID

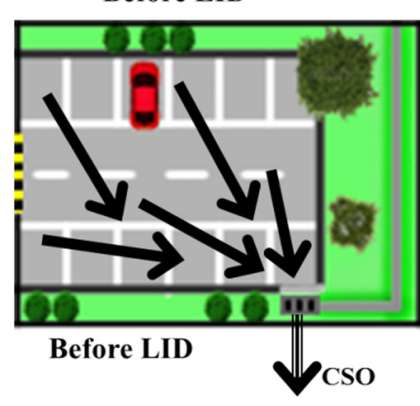

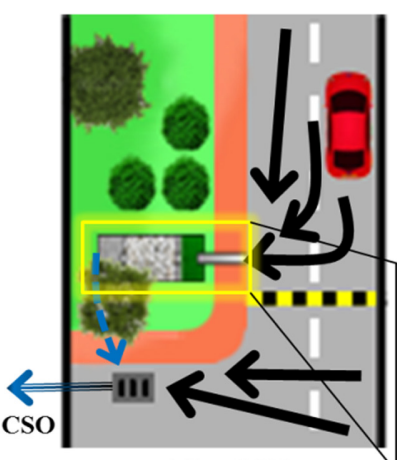

After LID

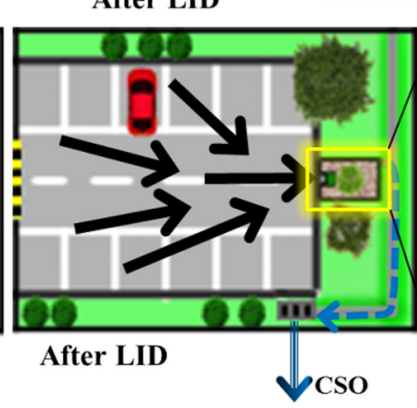

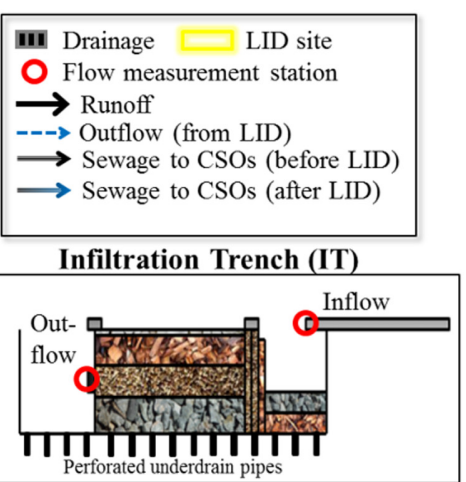

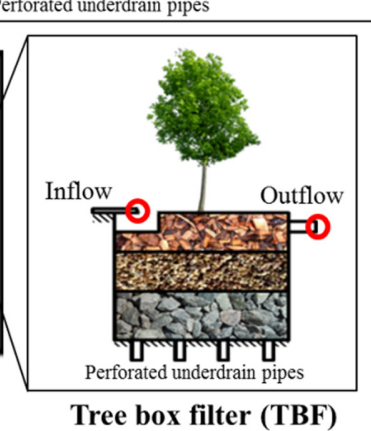

Fig. 1. Hydrologic condition before and after LID with the schematic diagrams of the infiltration trench and tree box filter utilized in LID. 


\section{Results and Discussion}

\subsection{Hydrologic Characteristics}

The rainfall frequency distribution in the LID sites for the monitoring period of 2010 to 2013 indicates that the total annual rainfall was highly variable for each year, smallest being $768 \mathrm{~mm}$ in 2013 and highest in 2012 with $2,212 \mathrm{~mm}$ (Fig. 2). In low rainfall year, the proportion of storms 15 $\mathrm{mm}$ or less accounts for $45 \%$ of the total annual rainfall; whereas in high rainfall years, it accounts for only $20 \%$. Since most of the storms that occurs in Korea (more than $70 \%)$ falls to the category of low-intensity rainfall $(15 \mathrm{~mm}$ or less) Maniquiz (2012) several stormwater management technologies were designed to control these most frequent storms. But as can be seen, a greater variation in rainfall distribution pattern has occurred recently due to climate change (e.g., occurrence of large storms greater than 70 $\mathrm{mm}$ ) making it more difficult to select appropriate rainfall conditions for LID.

The relationships of the runoff volume, average and peak flows before and after LID application are shown in Fig. 3. It was observed that the amount of runoff was greater than the storage capacity of the infiltration trench and tree box filter in $77 \%$ and $56 \%$ of storm events, respectively. Although there was a dominance of low rainfall storm events that were monitored, the runoff was fairly captured in the infiltration trench and tree box filter with an average runoff coefficient of 0.87 and 0.50 , respectively.

The rainfall that occurred in the paved road was effectively converted into stormwater runoff due to a steeper slope and lesser runoff interceptors (e.g. overhanging vegetation, parked vehicles, etc.) in the infiltration trench site that also resulted to higher rate of flows compared to the impervious parking lot in the tree box filter site. On average, the peak flows reached up to fourfold the average flows before LID. Apparently, the trendlines generated from the linear regression have high coefficient of determination $\left(R^{2}\right)$, and fall below the 1:1 line suggesting the hydrologic improvement contributed upon the application of the infiltration trench and tree box filter.

\subsection{Changes in the Hydrologic Balance}

The contribution of the infiltration trench and tree box filter on the hydrologic balance after LID was exemplified by the reduction in runoff volume (Table 1). The runoff before LID was completely discharged to sewers and possibly could lead to local flooding of transport systems and pollution to receiving waters during intense storm events. But

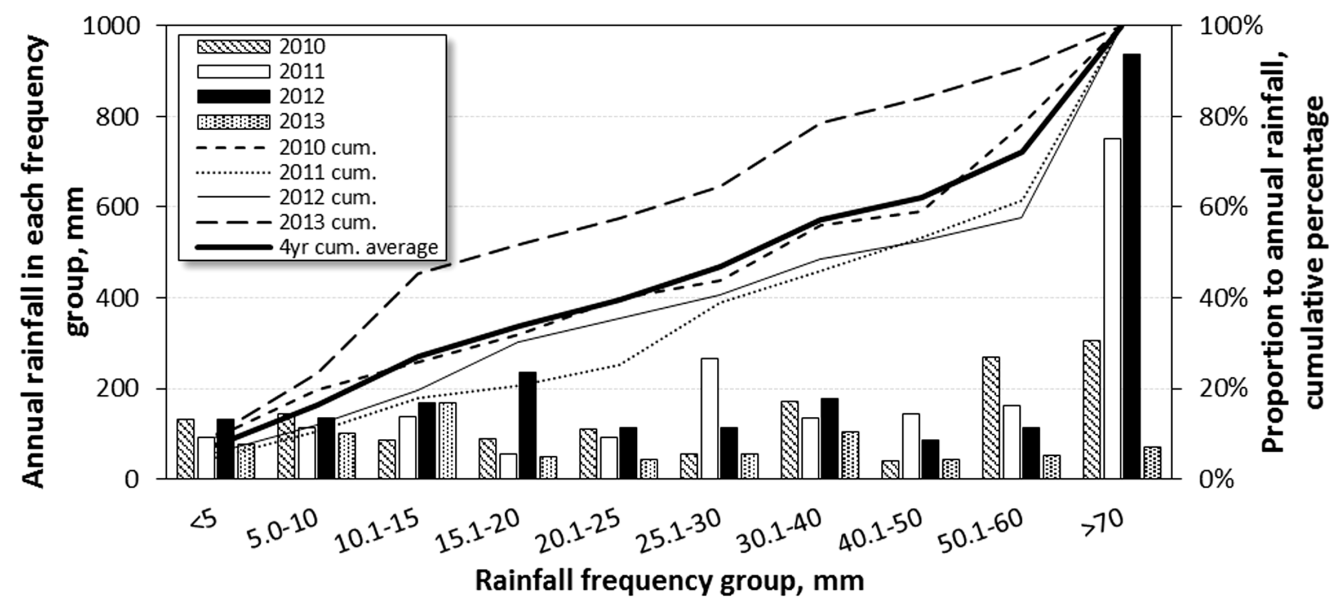

Fig. 2. Rainfall frequency distribution on the site, 2010 to 2013.
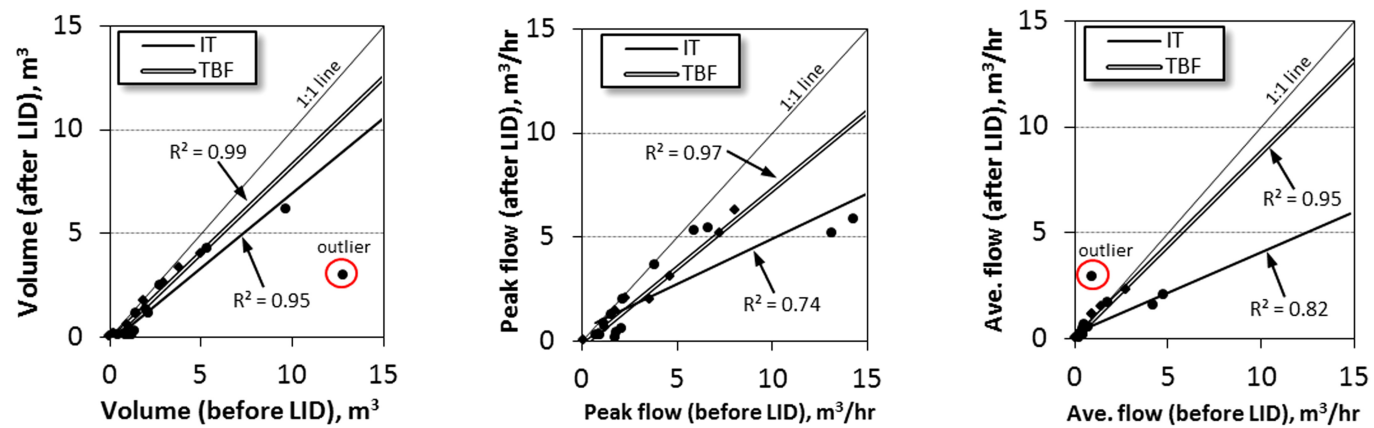

Fig. 3. Volume, average and peak flows before and after LID. 
Table 1. Hydrologic balance before and after LID

\begin{tabular}{c|c|c|c|c}
\hline \multirow{2}{*}{$\begin{array}{c}\text { Volume } \\
(\%)\end{array}$} & \multicolumn{2}{|c|}{ Infiltration trench } & \multicolumn{2}{c}{ Tree box filter } \\
\cline { 2 - 5 } & Before LID & After LID & Before LID & After LID $^{* *}$ \\
\hline \hline Runoff & $100 \%$ & $100 \%$ & $100 \%$ & $100 \%$ \\
\hline Reduced & $0 \%$ & $50.2 \pm 5.7 \%$ & $0 \%$ & $21.6 \pm 0.3 \%$ \\
\hline Discharge $^{*}$ & $100 \%$ & $49.8 \pm 5.4 \%$ & $100 \%$ & $78.4 \pm 1.5 \%$ \\
\hline
\end{tabular}

* Refers to the final percentage of runoff volume discharge to the sewer

${ }^{* *}$ Values refer to mean \pm standard deviation
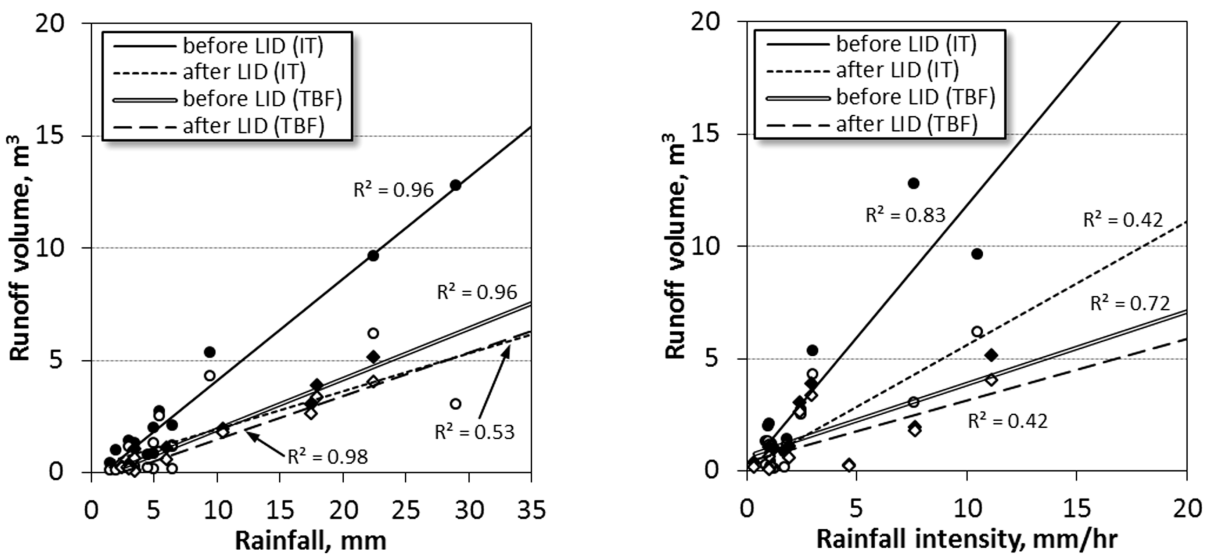

Fig. 4. Runoff volume as a function of rainfall and average rainfall intensity before and after LID.

after LID, the runoff was partially reduced by means of the combined processes of infiltration for groundwater recharge, retention for temporary storage of runoff, filtration and evapotranspiration that were provided by the infiltration trench and tree box filter. On average, the infiltration trench was able to reduce almost half the runoff generated from the paved road. The tree box filter only reduced $20 \%$ of the runoff but still satisfactory considering its small storage capacity compared to the catchment area that it drains.

It was observed that hydrologic parameters such as rainfall depth and rainfall intensity were factors that affect the runoff before LID and highly significant at the infiltration trench site than the tree box filter site (Fig. 4). When the rainfall depth was doubled, the difference in the amount of runoff volume before and after LID was increased by twofold in magnitude in the infiltration trench and about $115 \%$ in the tree box filter. As greater amount of runoff was generated in the infiltration trench than the tree box filter; the reduction in runoff volume before and after LID in the infiltration trench site was still evident $\left(1 \mathrm{~m}^{3}\right)$ even for rainfall as small as $5 \mathrm{~mm}$. However, in the case of tree box filter it requires at least $15 \mathrm{~mm}$ of rainfall in order to reduce at least $0.5 \mathrm{~m}^{3}$ of runoff.

It can be seen that as the rainfall increased, the volume reduction was becoming more apparent. For instance, when the rainfall was $10 \mathrm{~mm}$, almost $65 \%$ reduction was observed in the infiltration trench site; however, as the rainfall was further increased to $30 \mathrm{~mm}$, almost $90 \%$ reduction was achieved. In the tree box filter site, only $15 \%$ volume reduction was attained for $25 \mathrm{~mm}$ rainfall and could only reached $50 \%$ when the rainfall depth was $45 \mathrm{~mm}$. Similar observations were found in the case of rainfall intensity; the more intense rainfall, the greater amount of runoff was generated and also reduced. However, the influence of rainfall intensity in the volume reduction was not as prominent as the rainfall due to the lower correlation observed.

\subsection{Changes in the Magnitude, Frequency and Duration of Average and Peak Flows}

Based on Davis (2008), the peak flow reduction was an important parameter for quantifying the hydrologic impact of a particular stormwater management practice for LID. Fig. 5 shows the relationship of peak flows with the rainfall and rainfall intensity before and after LID application. Before LID, the peak flows in the infiltration trench site were 50 to $87 \%$ greater than the magnitude of peak flows in the tree box filter site that resulted due to a higher ground slope in the paved road $(90 \%$ greater than the parking lot slope) further promoting the surface runoff. The rainfall intensity showed a more apparent influence on the peak flow reduction compared to rainfall particularly in the infiltration trench site. For every unit increase in rainfall intensity, the average reduction in peak flow after LID was approximately $30 \%$ in the infiltration trench while only more than $5 \%$ in the tree box filter. The average monitored rainfall intensity on the sites (infiltration trench, $2.67 \mathrm{~mm} / \mathrm{hr}$ and 

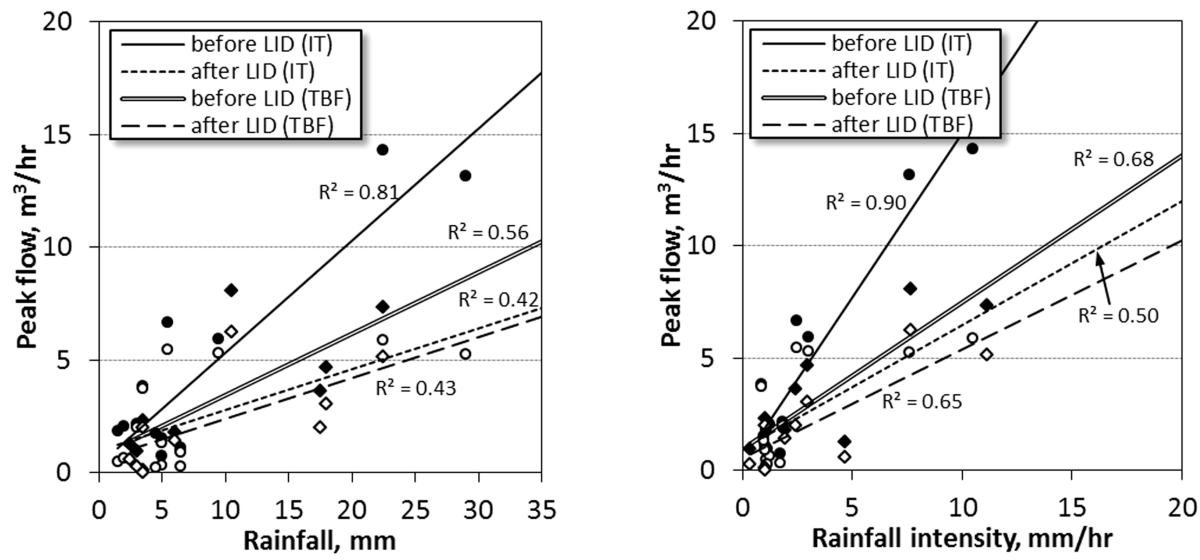

Fig. 5. Peak flows as a function of rainfall and average rainfall intensity before and after LID.

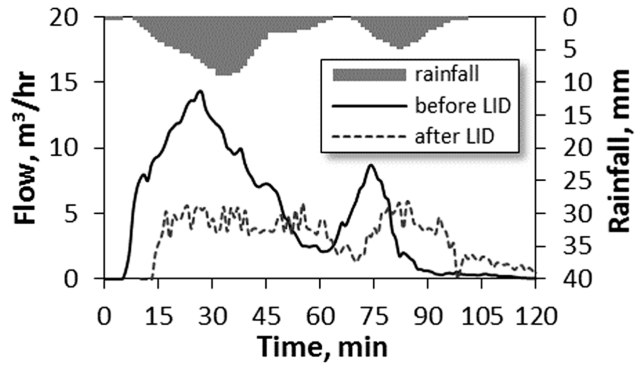

(a)

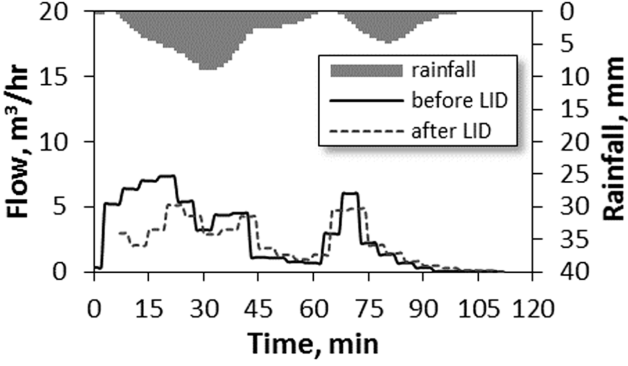

(b)

Fig. 6. Hydrographs for August 10, 2010 storm event at the (a) infiltration trench and (b) tree box filter.

tree box filter, $3.7 \mathrm{~mm} / \mathrm{hr}$ ) resulted to lower the peak flow by 2.2 and $0.9 \mathrm{~m}^{3} / \mathrm{hr}$ for infiltration trench and tree box filter, respectively. Although the value was lower in the tree box filter site, the peak flow was reduced by $5 \%$ greater than the infiltration trench site.

After LID, the minimum peak flow was reduced by $15 \%$ for infiltration trench at $3 \mathrm{~mm}$ rainfall; while $26 \%$ for tree box filter at the smallest rainfall of $1 \mathrm{~mm}$. As the rainfall increases so as the peak flows; the reduction in peak flows after LID was becoming more evident. The maximum monitored peak flow before LID (infiltration trench, $16 \mathrm{~m}^{3} / \mathrm{hr}$ and tree box filter, $8 \mathrm{~m}^{3} / \mathrm{hr}$ ) was reduced by $58 \%$ and $32 \%$ in the infiltration trench and tree box filter sites, respectively. Based on the regression analyses, insignificant increase in peak flow reduction was observed when rainfall was 40 and $30 \mathrm{~mm}$ for infiltration trench and tree box filter, respectively indicating that the maximum possible peak flow reduction was attainable at about $61 \%$ for infiltration trench and $33 \%$ for tree box filter.

Compared in Fig. 6 were the hydrographs for the infiltration trench and tree box filter for the same storm event that happened on August 10, 2010. It was observed that the flows resembled the rainfall distribution pattern but with a slight delay in the peaks due to surface runoff, typical in urban land use characterized by high impervious surfaces.
After LID, both sites exhibited a delay (lag time) or reduction in the magnitude, frequency and duration of flow peaks as the rainfall progress. Apparently, in the infiltration trench the average flows were greatly reduced; while the tree box filter was able to reduce the peak flows even not reducing a huge amount of runoff volume. Comparing the two, it was revealed that the infiltration trench having a larger storage capacity and subjected to high runoff and flows was able to perform more efficiently than the tree box filter. However, considering the catchment area of the infiltration trench that was only $13 \%$ larger than the tree box filter, the current storage capacity of the tree box filter could be maximize when applied to a smaller catchment.

\section{Conclusion}

Continuing urbanization imposed significant strains to the environment alongside with the climate change necessitating a need for a more sustainable stormwater practices like LID. In this research, the infiltration trench and tree box filter were utilized to implement the LID principle of restoring the hydrologic functions in urban catchments. Based on the results, it was found out that the magnitude of runoff and peak flows was dependent on the landuse characteristics such as imperviousness, slope, runoff interceptors, and most 
importantly the rainfall amount and intensity. After the application of infiltration trench and tree box filter, hydrological improvement was observed in the sites specifically changes in the hydrologic balance (runoff was reduced), magnitude, frequency and duration of peak flows. The runoff reduced in the sites were assumed to be infiltrated into the soil providing groundwater recharge, retained in the facility for temporary storage, or used by the plants.

Findings revealed that rainfall was the limiting factor in volume reduction and rainfall intensity in peak flow reduction indicating that as the rainfall increases so as the runoff volume, and as the rainfall intensity increases so as the peak flows; the reduction in runoff volume and peak flows after LID was becoming more evident. In the infiltration trench, the runoff volume and average flows were greatly reduced; while the tree box filter was still able to reduce the peak flows even not reducing a huge amount of runoff volume.

Comparing the two LID sites, the infiltration trench was able to perform more efficiently than the tree box filter due to higher runoff coefficient at the infiltration trench and larger storage capacity set against the catchment area. However, the capability of the tree box filter can be maximized when applied to a smaller catchment area. Consequently, the site selection for LID application should prioritize the sites subjected to high amount of runoff and it is recommended that the rainfall distribution pattern must be considered to select appropriate rainfall conditions for LID.

\section{국문요약}

도시화는 자연적 물순환을 왜곡하고 다양한 오염물질을 배출하여 환경 및 생태계에 영향을 끼친다. 특히 도시화로 인한 수문특성의 변화는 지하수위 저하, 첨두유량 중가로 인한 도시홍수 유발, 비점오염물질 배출 부하량 증가 등의 영향을 끼치기에 한국을 비롯한 선진국에서는 강우유출수 관리방안으로 LID 적용을 국가적 목표로 하고 있다. 그러 나 LID를 적용하였을 때의 수문학적 물순환 개선 및 환경 적 효과에 대한 실험적 검증결과가 부족하여 $\mathrm{LID}$ 의 적용 과 확산이 낮은 수준이다. 따라서 본 연구에서는 LID 기술 중에서 침투도랑과 나무여과상자를 적용한 이후 수문학적 효과를 실험적으로 분석하였다. 본 연구에 적용된 침투도랑 과 나무여과상자는 배수면적의 약 $1 \%$ 에 해당하는 면적을 가진 규모이며, 수문학적 효과 평가는 2010년 7월부터 2014년 7월까지 수행된 총 22회의 강우사상 모니터링 결과 를 이용하였다. LID 적용 이후 침투와 저류로 인하여 첨두 유량은 크게 감소하였으며, 첨두유량 발생시간도 크게 지체 되는 것으로 나타났다. 또한 LID 시설의 침투와 저류기능 은 강우유출수의 발생빈도, 유출발생시간 및 유출량을 크게 낮춘 것으로 나타나 LID 적용이 수문기능 회복에 크게 기 여하는 것으로 분석되었다. 최대 첨두유량의 저감의 경우,
강우량이 $30 \sim 40 \mathrm{~mm}$ 정도일 때 침투도랑에서 약 $61 \%$ 였으 며, 나무여과상자에서 $33 \%$ 였다. 이러한 연구결과로 볼 때 $\mathrm{LID}$ 는 수문기능 개선에 크게 기여하는 것으로 평가되었으 며, LID 설계시 저류능력과 배수면적이 중요한 설계인자가 될 수 있다는 결론을 도출하였다.

\section{Acknowledgement}

The funding for this research was financially supported by Construction Technology Innovation Program under the grant of Korea Agency for Infrastructure technology Advancement (KAIA) in the Ministry of Land, Infrastructure and Transport (Code\#'12 CTIP C03, Development of LID technology) in Korea. The authors were grateful for their support.

\section{References}

Coffman, L. (2000). Low Impact Development Design Strategies, An Integrated Approach, EPA 841-B-00-003, Department of Environmental Resources, Programs and Planning Division, Prince's George County, Maryland.

Cook, D. J. and Dickinson, W. T. (1985). The Impact of Urbanization on the Hydrologic Response of the Speedvale Experimental Basin, Ontario- A case study, in Proceedings, 1985 International Symposium on Urban Hydrology, Hydraulic Infrastructures and Water Quality Control.

Davis, A. (2008). Field performance of Bioretention: Hydrology impacts, Journal of Hydrologic Engineering, 13(2), pp. 90-95.

Davis, A. P., Hunt, W. F., Traver, R. G., and Clar, M. (2009). Bioretention Technology: Overview Practice and Future Needs, Journal of Environmental Engineering, 135(3), pp. 109-117.

Hatt, B. E., Fletcher, T. D., and Delatic, A. (2007). Treatment Performance of Gravel Filter Media: Implications for Design and Application of Stormwater Infiltration Systems, Water Research, 41(12), pp. 2513-2541.

Hood, M. J., Clausen, J. C., and Warner, G. S. (2007). Comparison of Stormwater Lag Times for Low Impact and Traditional Residential Development, Journal of the American Water Resources Association, 43(4), pp. 1036-1046.

Hsu, M. H., Chen, S. H., and Chang, T. J. (2000). Inundation Simulation for Urban Drainage Basin with Stormwater Sewer System, Journal of Hydrology, 234, pp. 21-37.

Jacobson, C. R. (2011). Identification and Quantification of the Hydrological Impacts of Imperviousness in Urban Catchments: A Review, Journal of Environmental Management, 92, pp. 14381448.

Kim, L. H. and Lee, S. (2005). Char Characteristics of Washed-off Pollutants and Dynamic EMCs in a Parking Lot and a Bridge during Storms, Journal of Korean Society on Water Environment, 21(3), pp. 372-379. [Korean Literature]

Lee, S. Y., Lee, E., Kim, C., Son, H., Maniquiz, M., Son, Y., Kang, H., Kim, J., and Kim, L. H. (2007). Characteristics of Wash-off Metal Pollutants from Highway Toll-Gate Area, Journal of Korean Society on Water Environment, 23(6), pp. 945950. [Korean Literature] 
Lee, S. Y., Lee, E., Maniquiz, M. C., and Kim, L. H. (2008). Determination of Pollutant Unit Loads from Various Transportation Landuses, Journal of Korean Society on Water Environment, 24(5), pp. 543-549. [Korean Literature]

Maniquiz, M. C. (2012). Low Impact Development (LID) Technology for Urban Stormwater Runoff Treatment- Monitoring, Performance and Design, $\mathrm{PhD}$ Thesis, Kongju National University: Department of Civil and Environmental Engineering, Cheonan City, South, Korea.

Maniquiz, M. C., Kim, L. H., Lee, S., and Choi, J. (2012). Flow and Mass Balance Analysis of Eco-bio Infiltration Systems, Frontiers of Environmental Science and Engineering, 6(5), pp. 612-619.

McCuen, R. H. (1998). Hydrologic Analysis and Design, 2nd edition, Prentice Hall: Upper Saddle River: New Jersey, pp. 814. Rose, S. and Peters, N. E. (2001). Effects of Urbanization on Streamflow in the Atlanta Area (Georgia, USA): A Comparative Hydrological Approach, Hydrological Processes, 15, pp. 14411457.

Shaw, E. M. (1994). Hydrology in Practice, 3rd edition, Chapman \& Hall: London, pp. 569.

Shuster, W. D., Bonta, J. Thurston, H., Warnemuende, E., and Smith D. R. (2005). Impacts of Impervious Surface on Watershed Hydrology: A Review, Urban Water Journal, 2(4), pp. 263-275.

United States Environmental Protection Agency (U.S EPA). (1999). Stormwater Technology Fact Sheet: Infiltration Trench, Office of Water, Washington DC. EPA 832-F-99-019. 